\title{
Pengaruh Latihan Peregangan Kaki Terhadap Pengisian Kapiler Pada Penderita Luka Ulkus Diabetes
}

\author{
Heru Purnomo ${ }^{1} *$ Mu'awanah $^{2}$ M. Nor Mudhofar ${ }^{3}$ Ajeng T Normawati ${ }^{4}$ Lilik Suprasno $^{5}$ \\ ${ }_{1,2,3,4,5}$ Program Studi D-III Keperawatan Blora, Poltekkes Kemenkes Semarang, Indonesia
}

\author{
*Corresponding author : Heru Purnomo \\ Email: purnomoheru0808@gmail.com
}

Received: 10 July 2020; Revised: 21 July 2020; Accepted: 17 August 2020

\begin{abstract}
Damage to tissues causes damage to blood vessels.In patients with DM with diabetic ulcers, perfusion repair is absolutely necessary because it will be very helpful in transporting oxygen and blood to the damaged tissue. A good indicator of perfusion is characterized by normal oxygen saturation support Physical exercise stretching the legs is the main treatment in the prevention and healing of diabetic foot ulcers. Research purposes Identifying the effect of Stretching Exercises on oxygen saturation in patients with diabetes mellitus ulcers. Research methods used is quasi-experimental (Quasi experiment designs) with the design of the Pre test and Post test nonequivalent control group design. Non-probability sampling technique with consecutive sampling technique. The study was conducted at the General Hospital dr. R. Soetijono Blora from May to November 2019 with a sample of 20 respondents. Univariate analysis includes descriptive analysis and bivariate analysis with Paired Samples Correlations and Paired Samples test. Research Results and Discussion showed stretching exercises (Stretching Exercises) correlated (Sig value $0,000<\alpha 0.005$ ) and effect (Sig 2 -tailed value $=0.001<1 / 2 \alpha 0.025$ ) on oxygen saturation in patients with diabetes mellitus ulcers on stretching days 2 and 3 Leg stretching exercises cause the muscles to contract continuously and activate the blood vessel system and venous pump so that blood circulation will increase. Leg stretching exercises (Stretching Exercises) in the Ankle section to improve the function of blood flow in the legs so that tissue requirements such as oxygen and nutrients are met, these exercises also have a positive impact on the healing process of diabetic foot ulcers or can optimize the vascularization of the ulcer area with indicators of improvement in oxygen saturation. Conclusions and Suggestions research on stretching exercises (stretching exercises) correlated and affected the oxygen saturation in patients with DM ulcers, after doing leg stretching exercises day 2 and 3.
\end{abstract}

Keyword : Leg stretching exercise, Oxygen saturation, Diabetic foot ulcers

\section{Introduction \\ (Pendahuluan)}

Pasien dengan DM berisiko terjadi komplikasi akut dan kronis. Komplikasi akut antara lain koma hiperglikemia, ketoasidosis, koma hipoglikemia. Komplikasi kronis antara lain mikroangiopati (retinopati, neuropati, nefropati), makroangiopati (kelainan pada jantung dan pembuluh darah, penyakit vaskuler perifer, gangguan sistem pembuluh darah otak) dan ulkus diabetik (Tarwoto, dkk, 2012, p. 161). Ulkus diabetik terdapat kerusakan sebagian atau keseluruhan pada kulit yang dapat meluas ke jaringan di bawah kulit, tendon, otot, tulang atau persendian yang terjadi pada seseorang yang menderita penyakit Diabetes Melitus (Tarwoto, dkk, 2012, p. 219).

Kerusakan pada jaringan menyebabkan kerusakan pada pembuluh darah. Ulkus diabetik merupakan salah satu bentuk gangguan pada ekstremitas bawah akibat dari komplikasi makrovaskuler yang dapat berakhir dengan amputasi. Pada pasien DM dengan ulkus diabetik, perbaikan perfusi mutlak diperlukan karena hal tersebut akan sangat membantu dalam 
pengangkutan oksigen dan darah ke jaringan yang rusak (Smeltzer \& Bare, 2010).

Perfusi sangat berhubungan erat dengan pengangkutan atau penyebaran oksigen yang adekuat ke seluruh lapisan sel dan merupakan unsur penting dalam proses penyembuhan luka (Smeltzer \& Bare, 2010). Perfusi yang baik ditandai dengan adanya waktu pengisian kapiler (capillary refill time / CRT) dan juga didukung saturasi oksigen yang normal.

Untuk mencegah dampak lebih lanjut perlu dilakukan berbagai upaya. Salah satu upaya mengontrol vaskuler yang sedang dikembangkan untuk meningkatkan saturasi oksigen pada penderita ganggren / ulkus kaki diabetic. Solusi untuk mencegah terjadinya kerusakan jaringan dengan Ulkus diabetik yaitu pencegahan agar tidak terjadi kecacatan yang lebih parah dan pencegahan sekunder dengan pengelolaan ulkus diabetik yang sudah terjadi (Sudoyo, Aru W, dkk. 2007, p. 1912).

Olahraga atau latihan jasmani merupakan salah satu cara pengelolaan dalam mengendalikan kadar gula darah pada penderita diabetes mellitus. Olah raga terutama nonkompetitif yang bersifat endurance, akan memperbaiki resistensi insulin. Latihan kaki juga dipercaya untuk mengelola pasien yang mengalami DM, pasien DM setelah latihan kaki merasa nyaman, mengurangi nyeri, mengurangi kerusakan saraf dan mengontrol gula darah serta meningkatkan sirkulasi darah pada kaki. Untuk meningkatkan vaskularisasi perawatan kaki dapat juga dilakukan dengan gerakan-gerakan kaki yang dikenal sebagai senam kaki diabetes (Smeltzer et al., 2010). Latihan fisik ROM Ankle merupakan tatalaksana utama dalam pencegahan dan penyembuhan luka ulkus kaki diabetik.

\section{Methods (Metode Penelitian)}

Jenis penelitian yang digunakan adalah penelitian eksperimen semu (quasi experiment). Penelitian ini berlokasi di RSUD dr. R. Soetijono Blora tepatnya di Ruang Flamboyan / Ruang Bedah. Penelitian dilaksanakan pada bulan Mei s/d November 2019.

Populasi penelitian adalah seluruh pasien penderita DM yang mempunyai luka Ulkus pada kaki di RSUD dr. R. Soetijono Blora. Sampel yang digunakan adalah berdasarkan kriteria inklusi penelitian diantaranya : Pasien DM dengan Luka Ulkus di kaki, Mendapatkan perawatan luka setiap hari, Memungkinkan dilakukan pengukuran pengisian kapiler, dan Bersedia menjadi responden. Tekhnik sampling yang digunakan secara non probability sampling dengan teknik consecutive sampling. Sampel penelitian terkumpul dalam rentang waktu mulai bulan Mei s/d November 2019 sejumlah 20 respnden. Pengumpulan data dilakukan secara bertahap yang meliputi : membentuk tim penelitian, yang membantu dalam prosedur penelitian dan monitoring serta pengumpulan data. Tim penelitian terdiri atas peneliti utama, anggota dan enumerator. Enumerator ditetapkan dengan kriteria perawat pelaksana dengan kualifikasi pendidikan minimal D3 dengan pengalaman perawatan luka minimal 5 tahun.

Melakukan koordinasi dan penyamaan persepsi antara peneliti dengan enumerator. Menentukan subjek penelitian berdasarkan kriteria inklusi yang telah ditetapkan. Memberikan penjelasan pada subjek penelitian dan meminta persetujuan atau kesediaannya menjadi sampel dalam penelitian. Melakukan pemeriksaan waktu pengisian kapiler dengan menekan lembut jari kaki sampai tampak putih, dan mencatat dari waktu yang dibutuhkan untuk perubahan warna kulit jari kaki dari warna putih menjadi kemerahan sekali tekanan dilepaskan. Waktu isi ulang yang normal adalah kurang dari 2 detik untuk dinilai sebelum dan sesudah dilakukan perlakuan. Melakukan perlakuan pada subjek dengan Latihan peregangan kaki (stretching exercises) sebelum dilakukan perawatan luka dengan gerakan dorsofleksi dan plantar fleksi, yang dilakukan masing masing 10 kali gerakan dan dilaksanakan selama 3 hari. Melakukan perawatan luka pada responden dengan konvensional dressing. Melakukan pemeriksaan waktu pengisian kapiler selama 3 hari sebelum dan sesudah dilakukan latihan peregangan kaki

Melakukan pencatatan seluruh hasil observasi dan pemeriksaan sesuai dengan pedoman pada form lembar observasi dan pemeriksaan yang telah disediakan. Uji validitas pengukuran waktu pengisian kapiler dilakukan sesuai prosedur tetap RSUD dr. R. Soetijono Blora dengan cara membersihkan jari kaki dengan bersih, selanjutnya menekan lembut jari kaki sampai tampak putih, dan mencatat dari waktu yang dibutuhkan untuk perubahan warna kulit jari kaki dari warna putih menjadi kemerahan sekali tekanan dilepaskan serta dicatat hasilnya. Uji reliabilitas pengukuran, peneliti sebelumnya melakukan pemeriksaan waktu pengisian kapiler minimal dua kali pada responden, kemudian dibandingkan antara hasil pengukuran pertama dan seterusnya.

Pengolahan dan analisis data fisik dalam penelitian ini dikumpulkan dengan menggunakan 
observasi/ pemeriksaan waktu pengisian kapiler. Pasien diperiksa waktu pengisian kapiler, kemudian melihat hasilnya. Analisis deskriptif dengan membuat tabel frekuensi, termasuk karakteristik responden yang meliputi usia, jenis kelamin, dan lama menderita ulkus DM, mengidentifikasi latihan peregangan kaki dan waktu pengisian kapiler. Analisis bivariat menggunakan uji Paired $T$ Test. Pada uji T kelompok berpasangan akan dilakukan uji sampel dengan mambandingkan hasil pemeriksaan awal (pre test) dibandingkan dengan hasil pemeriksaan akhir (post test).

\section{Results and Discussion (Hasil dan Pembahasan)}

Penelitian diawali proses perijinan di Kantor Kesatuan Bangsa dan Politik Kabupaten Blora pada tanggal 8 Juli 2019, kemudian dilanjutkan ke Kantor Bapeda Kabupaten Blora dan dilanjutkan ke Dinas Kesehatan Kabupaten Blora, serta RSUD dr. R. Soetijono Blora. Data karakteristik responden dapat dilihat pada tabel dibawah ini :

\begin{tabular}{lll}
\multicolumn{3}{l}{ Tabel 1. Distribusi Frekuensi } \\
Karakteristik Responden $(\mathrm{n}=20)$
\end{tabular}

Berdasarkan Tabel 1, Distribusi frekuensi karakteristik responden usia diketahui bahwa dari 20 responden, usia responden termuda $\leq 49$ tahun dan usia tertua 70 sampai dengan $\leq 79$ tahun, terbanyak adalah antara usia 50 - 69 tahun sebanyak 15 responden (75\%), Karakteristik jenis kelamin diketahui bahwa responden terbanyak adalah laki laki sebanyak 11 responden (55\%), sedangkan responden perempuan sebanyak 9 (45 $\%)$. Karakteristik pendidikan responden terendah adalah berpendidikan SD sebanyak 9 responden (45\%), sedangkan pendidikan responden tertinggi adalah berpendidikan Perguruan Tinggi sebanyak 2 responden (10\%). Karakteristik lama ulkus yang diderita responden $\leq 1$ minggu sebanyak 5 responden. (25\%), dan lama ulkus yang diderita responden $>1$ minggu sebanyak 15 responden $(75 \%)$.

Dari 20 responden usia responden termuda $\leq 49$ tahun dan usia tertua 70 sampai dengan $\leq 79$ tahun, terbanyak adalah antara usia 50 - 69 tahun sebanyak 15 responden $(75 \%)$. Umur responden diatas 49 tahun akan lebih berisiko terkena Diabetes Melitus yang berpotensi mengalami ulkus. Pendapat Suyono (2007) menjelaskan bahwa semakin bertambahnya usia maka tatalaksana fungsi tubuh akan terjadi penurunan, termasuk didalamnya terjadi penurunan fungsi sekresi maupun fungsi resistensi insulin, sehingga kemampuan untuk mengendalikan glukosa dalam darah menjadi kurang optimal. Penuaan juga akan mengakibatkan resiko terjadinya luka khususnya pada ekstremitas bawah yang disebabkan karena penurunan sirkulasi darah pada pembuluh darah besar atau sedang ditungkai akibat dari makroangiopati (Waspadji, 2006).

Hasil penelitian diketahui bahwa jenis kelamin responden terbanyak adalah laki laki sebanyak 11 responden $(55 \%)$, dan berpotensi seorang perokok aktif sehingga dapat mempengaruhi karakteristik luka Ulkus DM. Waspadji (2006) berpendapat bahwa pasien DM yang mempunyai kebiasaan merokok maka akan meningkatkan resiko tiga kali lebih besar terjadi komplikasi ulkus kaki Diabetik. Kandungan nikotin dalam rokok sangat berbahaya sehingga dapat berdampak terjadi kerusakan pada endotel, yang selanjutnya akan muncul agregrasi trombosit, kemudian muncul kebocoran yang akan mengakibatkan lipoprotein lipase memperlambat kinerja pembersihan lemak darah dan dapat beresiko terjadi aterosklerosis, sehingga akan mengakibatkan aliran pembuluh darah ke arah kaki akan menurun (Waspadji, 2006). Hal tersebut didukung oleh hasil penelitian Hokam (2009), yang melakukan penelitian pada 251 pasien Diabetes Melitus, dengan hasil ditemukan bahwa $70 \%$ pasien yang mengalami ulkus kaki diabetik adalah laki-laki karena merokok mempunyai faktor tiga kali resiko tinggi terhadap ulkus kaki diabetik.

Hasil Penelitian diketahui bahwa pendidikan responden terendah adalah berpendidikan SD sebanyak 9 responden (45\%), faktor pendidikan dapat mempengaruhi pengetahuan pasien tentang perawatan luka secara mandiri dirumah, dan nutrisi yang baik untuk luka ulkus Diabetik sehingga memiliki keterbatasan informasi atau pengetahuan tentang cara merawat luka dengan baik dan benar. Kurangnya pengetahuan responden ini juga 
disebabkan sebagian besar responden merupakan pasien baru yang mengalami ulkus kaki diabetik.

Hasil penelitian diketahui bahwa lama ulkus yang diderita responden terbanyak adalah lebih dari 1 minggu sebanyak 15 responden $(75 \%)$ yang termasuk dalam kelompok luka kronis yang beresiko akan mengalami kontaminasi, tetapi belum tentu luka tersebut mengalami infeksi. Untuk membuktikan bahwa luka tersebut mengalami infeksi perlu dilakukan uji laboratorium untuk mengatahui adanya peningkatan leukosit darah, dan ada tanda lain misalnya peningkatan suhu tubuh. Sedangkan pada warna dasar luka hitam dapat ditandai dengan terdapatnya jaringan nekrotik dan escar yang mengeras, mungkin kering atau lembab merupakan jaringan avaskularisasi (Tholib, 2016). Hal tersebut dapat dipengaruhi oleh pengalaman dan informasi responden tentang ulkus kaki diabetik yang kurang maka pengetahuan tentang ulkus diabetik tidak akan meningkat, sebaliknya jika penderita mempunyai pengalaman dan informasi seperti pernah menerima informasi dan penyuluhanpenyuluhan tentang ulkus diabetik maka pengetahuan penderita tentang ulkus semakin tinggi pula.

Data korelasi latihan peregangan kaki (stretching exercises) terhadap waktu pengisian kapiler dapat dilihat pada tabel dibawah ini :

Tabel 2. Korelasi Latihan Peregangan Kaki (stretching exercises) terhadap Waktu Pengisian Kapiler $(n=20)$

\begin{tabular}{|c|c|c|c|c|}
\hline Hari & Pengukuran & $\mathrm{N}$ & Correlation & Sig. \\
\hline I & $\begin{array}{l}\text { Tdk } \\
\text { Peregangan } \\
\& \text { dengan } \\
\text { Peregangan }\end{array}$ & 20 & ,815 & ,000 \\
\hline II & $\begin{array}{l}\text { Tdk } \\
\text { Peregangan } \\
\& \text { dengan } \\
\text { Peregangan }\end{array}$ & 20 & ,582 & ,007 \\
\hline III & $\begin{array}{l}\text { Tdk } \\
\text { Peregangan } \\
\& \text { dengan } \\
\text { Peregangan }\end{array}$ & 20 & ,793 & ,000 \\
\hline
\end{tabular}

Berdasarkan Tabel 2 diketahui bahwa korelasi latihan peregangan kaki (stretching exercises) terhadap waktu pengisian kapiler dengan nilai Sig $(0,000)$ pengukuran hari I, dan pengukuran hari ke III dengan nilai $(0,000)<\alpha(0,005)$, maka ada hubungan antara sebelum latihan peregangan dan sesudah latihan peregangan dengan nilai waktu pengisian kapiler pada penilaian hari pertama dan hari ketiga.

Hal tersebut dapat dijelaskan bahwa waktu pengisian kapiler pada pasien yang mengalami diabates mellitus akan terjadi perlambatan yang biasanya $>2$ detik. Pada kondisi CRT $>2$ detik, menurun denyut nadi perifer, warna kulit kaki yang pucat, akral kulit yang dingin merupakan indikasi iskemia. (Fleming, et al., 2016).

Pada pasien DM dengan ulkus diabetik, perbaikan perfusi mutlak diperlukan karena hal tersebut akan sangat membantu dalam pengangkutan oksigen dan darah ke jaringan yang rusak. Bila perfusi perifer pada luka tersebut baik maka akan baik pula proses penyembuhan luka tersebut. Penyebaran oksigen yang adekuat ke seluruh lapisan sel merupakan unsur terpenting dalam proses penyembuhan luka (Smletzer \& Bare. 2001).

Menurut Smeltzer \& Bare (2010), latihan ROM Ankle yang dilakukan secara kontinyu dan serius akan bermanfaat terutama bagi penderita ulkus kaki diabetik, seperti menurunkan kadar glukosa darah dan memperbaiki sirkulasi darah. Pada saat latihan peregangan Kaki (Stretching Exercises) maka otot berkontraksi terus menerus dan mengaktifkan sistem pembuluh darah serta pompa vena sehingga sirkulasi darah akan mengalami peningkatan. Fungsi saraf dan pemompaan darah kejantung menjadi lebih aktif sehingga mengaktifkan suplai oksigen dan nutrisi dengan baik (Ganong, 2008; Semendawai 2013).

Tabel 3. Pengaruh Latihan Peregangan Kaki (stretching exercises) terhadap Waktu Pengisian Kapiler $(n=20)$

\begin{tabular}{|c|c|c|c|c|}
\hline Hari & Pengukuran & Mean & $\mathrm{t}$ & $\begin{array}{l}\text { Sig. } \\
\text { tailed) }\end{array}$ \\
\hline \multirow[t]{4}{*}{ I } & Tdk & & & \\
\hline & Peregangan & , 150 & 1,831 & ,083 \\
\hline & $\&$ dengan & & & \\
\hline & Peregangan & & & \\
\hline \multirow[t]{4}{*}{ II } & $\mathrm{Tdk}$ & & & \\
\hline & Peregangan & 450 & 3,943 & ,001 \\
\hline & \& dengan & & & \\
\hline & Peregangan & & & \\
\hline \multirow[t]{4}{*}{ III } & $\mathrm{Tdk}$ & & & \\
\hline & Peregangan & ,050 & 1,000 & ,330 \\
\hline & \& dengan & & & \\
\hline & Peregangan & & & \\
\hline
\end{tabular}

Berdasarkan Tabel 3 diketahui bahwa pengaruh latihan peregangan kaki (stretching exercises) terhadap waktu pengisian kapiler dengan nilai Sig (2-tailed $=0,001)<1 / 2 \alpha(0,025)$, maka latihan peregangan kaki (stretching exercises) berpengaruh terhadap waktu pengisian kapiler pada penilaian hari kedua.

Hal tersebut dapat dijelaskan bahwa latihan peregangan kaki (stretching exercises) yang dilakukan sama halnya dengan pijat kaki akan memberikan tekanan dan gerakan pada kaki, 
sehingga akan mempengaruhi meningkatan sekresi endorphin yang berfungsi sebagai menurunkan rasa sakit, vasodilatasi pembuluh darah sehingga meningkatkan aliran darah ke jaringan perifer. Latihan peregangan kaki (stretching exercises) akan membantu gula darah mendekati batas normal, Capillary Refill Time (CRT) kembali $<3$ detik, perfusi hangat, terjadi penurunan skala nyeri (Aria \& Arisfa, 2016; Sukron, 2016).

Secara umum bahwa hasil pemeriksaan waktu pengisian kapiler dipengaruhi oleh banyak faktor eksternal yang berbeda sehingga tidak boleh diandalkan sebagai ukuran diagnostik secara umum (King, D, 2013).

Keterbatasan yang penulis jumpai pada proses penelitian ini diantaranya keterbatasan jumlah responden, kondisi dan jenis luka ulkus kaki diabetik responden, serta kualitas latihan peregangan kaki (stretching exercises) responden yang sangat bervariasi, sehingga dapat mempengaruhi waktu pengisian kapiler pada penderita luka Ulkus Diabetes Melitus, dan keterbatasan waktu dari peniliti sendiri.

\section{Acknowledgements (Ucapan Terimakasih)}

Ucapan banyak terimakasih kami sampaikan atas kesempatan yang diberikan untuk mendapatkan Dana Penelitian DIPA Politeknik Kesehatan Kemenkes Semarang tahun 2019 , sehingga kegiatan penelitian tentang "Pengaruh Latihan Peregangan Kaki (Stretching Exercises) terhadap Waktu Pengisian Kapiler pada Penderita Luka Ulkus Diabetes Melitus" pada tahun 2019 dapat terselesaikan.

\section{References (Daftar Pustaka)}

1. Aria Wahyuni, Nina Arisfa. (2016). Senam Kaki Diabetik Efektif Meningkatkan Ankle Brachial Index Pasien Diabetes Melitus Tipe 2. JURNAL IPTEKS TERAPAN Research of Applied Science and EducationV9.i2(155-

164).http://dx.doi.org/10.22216/jit.2015.v9i2 .231

2. Arwani, Puji Siswanto, Ramelan Sugijana. (2014). Perbedaan Tingkat Perfusi Perifer Ulkus Kaki Diabetik sebelum dan sesudah olah raga Pernafasan Dalam di Ruang Wijaya Kusuma RSUD dr. R. Soeprapto Серu. Prosiding Konferensi Nasional II PPNI Jawa Tengah. 2014
3. Carpenito, LyndaJuall \& Moyet. (2007). Buku Saku Diagnosis keperawatan. Terjemahan oleh Monica Ester. Jakarta : EGC.

4. $\quad$ Fleming, S., Van Den Bruel, A., Gill, P. J., \& Thompson, M. (2016). Capillary refill time in sick children: A clinical guide for general practice. British Journal of General Practice, 66(652), 587-588. https:// doi.org/10.3399/bjgp16X687925

5. Ganong, W. F. (2008). Buku Ajar Fisiologi Kedokteran. Edisi 22. Jakarta: EGC

6. Goldsmith, J.R., Lidtke, RH., \& Shott, S. (2002). The Effects Range Of Motion Therapy On The Plantar Pressures Of Patients With Diabetes Melitus. Journal of the american pdiatric medical association, 92(9), 483-490

7. Hayens R. B., Frans H. L., \& Eddy S. (2008). Buku Pintar Menaklukkan Hipertensi. Jakarta: Ladang Pustaka \& Intimedia

8. Hokkam, EN. (2009). Assesment of Risk Factors in Diabetic Foot Ulceration and Their Impact on the Outcome of the Disease. Primary Care Diabetes 3 (2009) 219-224

9. Huang, E.S., Basu, A., O'Grady, M., \& Capreta, J.C. (2009). Projecting the Future Diabetes Population Size and Related Costs for the U.S. Diabetes Care, 32: 2225229.doi:10.2337/dc09-0459

10. Jannaim, Ridha Dharmajaya, Asrizal. (2018). Pengaruh Buerger Allen Exercise Terhadap Sirkulasi Ekstremitas Bawah Pada Pasien Luka Kaki Diabetik. Jurnal Keperawatan Indonesia, Volume 21 No.2, Juli 2018, hal 101-108 pISSN 1410-4490, eISSN 2354-9203. DOI: $10.7454 /$ jki.v21i2.652

11. Karen Ousey, ed All. (2018). Identifying and treating foot ulcers in patients with diabetes: saving feet, legs and lives. Published Online: $8 \quad$ May 2018 https://doi.org/10.12968/jowc.2018.27.Sup5. $\underline{\mathrm{S} 1}$

12. King, D; Morton, R; Bevan, C (13 November 2013). "Bagaimana menggunakan waktu isi ulang kapiler". Archives of Disease in Childhood: Edisi Pendidikan dan Praktik. 99 (3): 111-116

13. Kozier,Barbara., dkk. (2011).Buku Ajar Fundamental Keperawatan: Konsep, proses, danpraktik.TerjemahanolehDwiWidiarti, dkk. Jakarta : EGC.

14. PPNI. (2017). Standar Diagnosa Keperawatan Indonesia Definisi Dan 
Indikator Diagnostik, Edisi I, DPP PPNI. Jakarta

15. Sarefi, Andra\& Mariza, Yessi. (2013). Keperawatan Medikal Bedah 2 (KeperawatanDewasa). Yogyakarta: Nuha Medika.

16. Siti Fadlilah. (2018). Faktor Faktor Yang Berhubungan Dengan Derajat Ulkus Kaki Diabetik Di RSUD dr. Moerwadi Surakarta.

17. Jurnal Ilmiah Rekam Medis dan Informatika Kesehatan. INFOKES, VOL 8 NO 1, Februari 2018. ISSN : $2086-2628$.

18. Smeltzer \& Bare. (2010). Buku Ajar Keperawatan Medikal Bedah,. Edisi 8 Brende G.Bare; Ahli Bahasa, Agung Waluyo dkk. Jakarta: EGC

19. Sri Hananto Ponco Nugroho, Dikna Puspitasari. ( ). Range Of Motion (Rom) Ankle Untuk Mempercepat Penyembuhan Luka Ulkus Kaki Diabetik Berdasarkan Karakteristik Warna Luka. Buku Proceeding Unissula Nursing Conferenc. Tema : Nurse Roles in Providing Spiritual Care in Hospital, Academic and Community

20. Sudoyo, Aru W.,dkk.(2007). Buku Ajar Ilmu Penyakit Dalam.Jilid III, Edisi IV. Jakarta : IPD FKUI.

21. Sukron, M. (2016). Penerapan Diabetic Foot Exercise Pada Pasien Diabetes Mellitus Dengan Masalah Keperawatan Ketidakefektifan Perfusi Jaringan Perifer Di Ruang Azzara I RSI Surabaya Jemursari. Universitas NU Surabaya.

22. Suyono, S (2007). Buku Ajar Ilmu Penyakit Dalam. Jakarta: Penerbitan Departemen Penyakit Dalam Fakultas Kedokteran Universitas Indonesia

23. Tarwoto, dkk. (2012). Keperawatan Medikal Bedah Gangguan Sistem Endokrin. Jakarta : Trans Info Medika.

24. Waspadji, S. (2006). Kaki Diabetes. Dalam: Buku Ajar Ilmu Penyakit Dalam. Jilid 3 Edisi IV. Jakarta: Departemen Ilmu Penyakit Dalam Fakultas Kedokteran Universitas Indonesia

25. Wibisono. (2009). Senam Khusus Untuk Penderita Diabetes. http://senamkaki.com

26. Widyawati, I.Y. (2010). Pengaruh latihan Gerak Sendi Bawah Aktif (Active Lower Range of Motion Exercise) Terhadap Tanda Dan Gejala Neuropati Diabetikum Pada Penderita DM tipe II di PERSADIA unit RSU Dr. Sutomo Surabaya (Tesis Magister). lib.ui.ac.id/file?file $=$ digital/13724

27. Wilkinson Judith \& Ahern Nancy.(2012).
BukuSaku
Diagnosis
Keperawatan

:Diagnosis NANDA, Intervensi NIC, Kriteria Hasil NOC. Terjemahan oleh Dwi Widiarti. Jakarta : EGC.

28. Wulandari, I., Yetti, K., \& Hayati, R.T. (2011). Pengaruh Elevasi Ekstermitas Bawah Terhadap Proses Penyembuhan Ulkus Diabetik Di Wilayah Banten. Repository University of Riau. https://repository.unri.ac.id/xmlui/bitstream/ handle/123456789/7472/Artikel\%20Indah\% 20(Banten) 